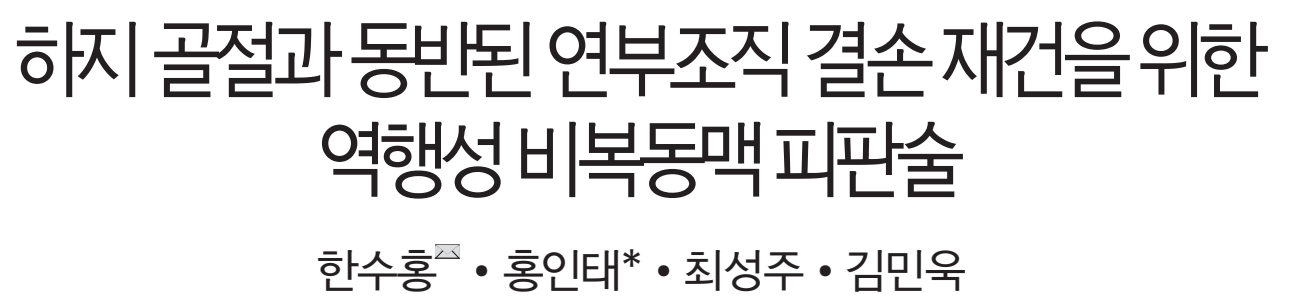

차의과학대학교 분당차병원 정형외과학교실, *한림대학교 동탄성심병원 정형외과

\title{
Reverse Superficial Sural Artery Flap for the Reconstruction of Soft Tissue Defect Accompanied by Fracture of the Lower Extremity
}

\author{
Soo-Hong Han, M.D., Ph.D. ${ }^{\bowtie}$, In-Tae Hong, M.D.*, SeongJu Choi, M.D., and Minwook Kim, M.D. \\ Department of Orthopaedic Surgery, CHA Bundang Medical Center, CHA University, Seongnam, \\ ${ }^{\star}$ Department of Orthopaedic Surgery, Hallym University Dongtan Sacred Heart Hospital, Hwaseong, Korea
}

Purpose: Soft tissue defects of the distal lower extremity are commonly accompanied by a fracture of the lower extremities. Theses defects are caused by the injury itself or by complications associated with surgical treatment of the fracture, which poses challenging problem. The reverse superficial sural artery flap (RSSAF) is a popular option for these difficult wounds. This paper reviews these cases and reports the clinical results.

Materials and Methods: Between August 2003 and April 2018, patients who were treated with RSSAF for soft tissue defects of the lower third of the leg and ankle related to a fracture were reviewed. A total of 16 patients were involved and the mean follow-up period was 18 months. Eight cases (50.0\%) of the defects were due to an open fracture, whereas the other eight cases $(50.0 \%)$ were postoperative complication after closed fracture. The largest flap measured $10 \times 15 \mathrm{~cm}^{2}$ and the mean size of the donor sites was $51.9 \mathrm{~cm}^{2}$. The flap survival and postoperative complications were evaluated.

Results: All flaps survived without complete necrosis or failure. One case with partial necrosis of the flap was encountered, but the wound healed after debridement and repair. One case had a hematoma with a pseudoaneurysmal rupture of the distal tibial artery. On the other hand, the flap was intact and the wound healed after arterial ligation and flap advancement. A debulking operation was performed on three cases for cosmetic reasons and implant removal through the flap was performed in three cases. No flap necrosis was encountered after these additional operations.

Conclusion: RSSAF is a relatively simple and safe procedure for reconstructing soft tissue defects following a fracture of the lower extremity that does not require microsurgical anastomosis. This can be a useful treatment option for soft tissue defects on the distal leg, ankle, and foot.

Key words: lower extremity, soft tissue defect, reverse superficial sural arterial flap

\section{서 론}

하지, 특히 정강이 앞부분이나 발, 발목에서의 연부조직 결손은

Received March 19, 2019 Revised May 8, 2019 Accepted July 11, 2019

Correspondence to: Soo-Hong Han, M.D., Ph.D.

Department of Orthopaedic Surgery, CHA Bundang Medical Center, CHA University, 59 Yatap-ro, Bundang-gu, Seongnam 13496, Korea

TEL: +82-31-780-5289 FAX: +82-31-708-3578 E-mail: hsoohong@cha.ac.kr ORCID: https://orcid.org/0000-0002-8951-650X
다른 부위에 비해 연부조직이 상대적으로 얇고 적어 피복에 복잡 한 술기가 적용되어야 하는 경우가 흔한데 결손의 원인으로는 외 상(39.4\%), 당뇨 및 혈관 손상에 의한 궤양성 병변(16.3\%), 개방 성 골절(10.5\%), 그리고 수술 후 합병증(6\%) 등이 알려져 있다. ${ }^{1)}$ 
Soo-Hong Han, etal.

연부조직의 결손이 건, 혈관, 신경, 그리고 뼈와 같은 중요 구 조물을 노출시킬 경우 피부 이식술은 제한된 두께로 인해 적용이 부적절해서 여러 가지 피판술을 고려해야 한다. 피복을 위한 여 러 방법으로 국소피판술, 근이동술, 도서형피판술, 유리피판술 등 이 적용될 수 있는데, 유리피판술은 재건 집도의들의 표준방식으 로 자리잡았으나 긴 시술시간, 현미경적 미세수술이 필요해 기술 적으로 부담이 크며, 그에 따른 실패 위험와 같은 제한점이 존재 한다. ${ }^{2)}$

역행성 표재성 비복동맥 피판술은 현미경적 미세수술을 필요 로 하지 않아 상대적으로 술기가 간편하면서 안전하여 하지 원위 부, 발목, 그리고 발뒤꿈치의 결손부의 치료에 있어 유용한 술기 이다. 1992년 Masquelet 등3)은 하지에서 표재 감각신경과 동반 되는 동맥의 역할을 연구하였고, 그 결과 복재신경, 표재 비골신 경, 비복신경에 분포하는 혈관이 그 주위의 피부에도 혈류를 공 급한다는 데 근거한 신경피부 피판술(neurocutaneous flap)을 발표하였다. 이는 회전원호가 길고, 박리가 용이하며, 혈액공급이 안정적이어서 원위부 하지, 발목, 족부의 피부재건에 중요한 술 식으로 빠르게 받아들여졌으며, 다양한 응용법이 적용되어 좋은 결과를 보고하고 있다.

저자들은 골절 후 발생한 하지의 다양한 연부조직 결손에 대하 여 역행성 비복동맥 피판술을 사용하여 피복을 시행한 예들을 수 집, 분석하여 해당 술식의 유용성과 신뢰성을 보고하고자 하였
다.

\section{대상 및 방법}

\section{1. 연구대상}

2003년 8월부터 2018년 4월까지 하지 원위부, 발목 및 발의 개 방성 골절 또는 폐쇄적 골절 후 수상 부위에 발생한 연부조직 결 손에 대해 역행성 비복동맥 피판술을 시행 받은 환자의 방사선 검사, 의무기록, 창상 사진 자료를 후향적으로 검토하였으며 그 중에서 수술 후 최소 6개월 이상 추시가 가능했던 환자를 대상으 로 하였다. 추시 기간이 6 개월보다 짧거나 추시가 불가했던 환자 는 대상에서 제외하였다. 총 16 명의 환자를 대상으로 하였으며, 평균 추시기간은 18 개월이었다. 남자는 14 명, 여자는 2 명이었고 평균연령은 50.4세(18-70세)였다. 재건술이 이루어진 부위는 하 퇴 원위부 7예, 발목부위 5예, 발뒤꿈치 부위 4예였다. 연부조직 결손의 원인으로는 개방성 골절 자체로 인한 결손이 회복되지 못 한 예가 8건, 폐쇄성 골절에 대해 관혈적 정복술 및 내고정술을 시행한 후 피부괴사가 발생한 예가 8건이었다. 피판의 크기는 평 균 $51.9 \mathrm{~cm}^{2}$, 가장 큰 피판은 $10 \times 15 \mathrm{~cm}^{2}$ 였으며, 공여부에 일차 봉합을 시행한 사례가 3 예, 부분층 피부이식을 사용한 사례가 8 예, 전층 피부이식을 사용한 사례가 5예였다(Table 1).

피판술은 환자의 전신 상태의 회복과 함께 피부 결손 부위에

Table 1. Patients and Wound Characteristics (1)

\begin{tabular}{|c|c|c|c|c|c|c|}
\hline $\begin{array}{c}\text { Case } \\
\text { no. }\end{array}$ & Age (yr)/Sex & Cause & Site of defect & $\begin{array}{c}\text { Flap size } \\
\left(\mathrm{cm}^{2}\right)\end{array}$ & Additional surgery & Donor closure \\
\hline 1 & 66/Female & Postoperative skin necrosis & Medial malleolus & $6 \times 6$ & None & Primary closure \\
\hline 2 & 36/Male & Open fracture & Anterior, distal leg & $10 \times 10$ & None & STSG \\
\hline 3 & 46/Male & Open fracture & Heel & $9 \times 6$ & Hardware removal & STSG \\
\hline 4 & 56/Male & Open fracture & Anteromedial, distal leg & $12 \times 9$ & None & STSG \\
\hline 5 & 27/Male & Open fracture & Anteromedial, distal leg & $10 \times 15$ & Debridement & STSG \\
\hline 6 & 55/Male & Postoperative skin necrosis & Heel & $5 \times 5$ & None & FTSG \\
\hline 7 & 70/Female & Postoperative skin necrosis & Heel & $5 \times 5$ & None & STSG \\
\hline 8 & 55/Male & Postoperative skin necrosis & Medial malleolus & $7 \times 7$ & None & Primary closure \\
\hline 9 & 27/Male & Open fracture & Heel & $4 \times 4$ & Hardware removal & Primary closure \\
\hline 10 & 70/Male & Open fracture & Lateral malleolus & $4 \times 3$ & Debulking & STSG \\
\hline 11 & 18/Male & Postoperative skin necrosis & Lateral malleolus & $5 \times 4$ & Debulking & STSG \\
\hline 12 & 49/Male & Open fracture & Anterior, distal leg & $7 \times 5$ & Revision OR/IF d/t nonunion & STSG \\
\hline 13 & 62/Male & Postoperative skin necrosis & Anteromedial, distal leg & $10 \times 8$ & Hematoma evacuation & FTSG \\
\hline 14 & 58/Male & Postoperative skin necrosis & Anterior, distal leg & $8 \times 6$ & Debulking & FTSG \\
\hline 15 & 65/Male & Postoperative skin necrosis & Lateral malleolus & $5 \times 5$ & None & FTSG \\
\hline 16 & 46/Male & Open fracture & Anterior, distal leg & $8 \times 6$ & None & FTSG \\
\hline
\end{tabular}

OR/IF, open reduction/internal fixation; d/t, due to; STSG, split thickness skin graft; FTSG, full thickness skin graft. 
Reverse Superficial Sural Artery Flap

연부조직 발적, 열감, 삼출물 및 배농 등의 감염 가능성이 임상적 으로 완전히 배제된 상태에서 시행하였다. 골절 발생일로부터 피 판술까지 소요된 기간은 평균 150 일이었는데, 만성골수염의 조 절(1,235일 소요) 후 수술이 필요했던 1예, 관혈적 정복술 및 내 고정술 후 불유합으로 추가수술을 받고 연부조직 결손이 발생한 3예(각 167일, 151일, 311일 소요)를 제외하면, 피판술까지 소요 된 평균 기간은 44.6일이었다(Table 2). 평균수술시간은 117 분, 최소시간은 65 분이었고 최장시간은 195 분이었다. 결과 분석을 위해 수술 후 피판의 생존 여부와 추가 술식, 합병증 등을 조사하 였다.

\section{2. 수술방법}

전신 마취 또는 척추 마취하 환자를 복와위 또는 측와위 자세로 수술을 시행하였다. 이동형 도플러 장비를 이용하여 발목관절 외

Table 2. Patients and Wound Characteristics (2)

\begin{tabular}{lc}
\multicolumn{1}{c}{ Characteristic } & Value \\
Average days from injury to flap (d) ${ }^{\star}$ & $150(14-1,235)$ \\
Osteomyelitis & 1,235 \\
Chronic progressive defect & \\
After provisional ORIF & 167 \\
After provisional ORIF & 151 \\
After 2nd provisional ORIF & 311 \\
Average days from injury to flap (d) & 44.6 \\
Operation time (min) & $117(65-195)$ \\
\hline
\end{tabular}

Values are presented as mean (range) or mean only. *Including all cases. ${ }^{\dagger}$ Except remarkable 4 cases. ORIF, open reduction and internal fixation.
측과 후방부에 비골동맥 관통지의 위치를 표시하였으며 이는 일 반적으로 발목관절 외측과로부터 약 $3-5 \mathrm{~cm}$ 근위부에 해당한다. 피판은 결손부 크기에 따라 하퇴 후면에 작도하였다. 피판의 회 전 중심(pivot point)은 표시한 비골동맥 관통지로 정하고 회전 중심으로부터 결손부 원위부까지의 거리를 잰 다음 그 거리만큼 을 회전 중심으로부터 근위부로 거리를 재어 표시하였고 그 지점 을 피판의 가장 근위부로 정한다. 이 지점을 기준으로 피판의 형 태를 타원형으로 그리고, 피판의 원위부는 피판경 위 피부가 긴 장 없이 봉합될 수 있도록 눈물방울(teardrop) 모양으로 하였다. 작도한 피판의 모양대로 종이를 오리고 피판의 회전 중심을 기준 으로 회전시켜 결손 부위를 충분히 덮을 수 있는지 확인하였다. 이후 수술할 부위를 소독하여 준비하고 지혈대로 압박한 뒤 결손 부의 변연절제 및 세척을 시행하였다. 피판의 박리는 근위부에서 부터 시작하였으며 우선 비복신경과 소복재정맥을 확인하여 결 찰하였다. 이 후 피판의 근위부부터 근막 하면을 거상하여 원위 부로 진행하였다. 피판의 피부는 눈물방울 모양으로 절개하였고 피하경피판(pedicle)은 폭이 최소 3-4 cm가 되도록 유지하여 상 근막망(suprafascial network) 문합이 보존되도록 하였다. 회전 중심의 인접부위까지 근막 하면을 따라 거상하였으며 회전 중심 에 인접한 관통지는 최대한 보존하면서 거상한 피판이 결손 부위 를 완전히 덮을 수 있도록 충분히 박리하였다. 이후 지혈대를 풀 어 피판의 혈액순환을 확인하고 피판을 원위부로 이동시켜 결손 부에 봉합하였다(Fig. 1). 공여부는 가능하면 일차 봉합술을 시행 하지만 일차 봉합이 불가능한 경우에는 부분 혹은 전층 피부이식 술을 시행하였다. 수술 후 피판 부위는 상시 확인할 수 있도록 투 명한 플라스틱 덮개로 덮어 두었으며 창상 소독 후 부목 고정을 시행하였다.
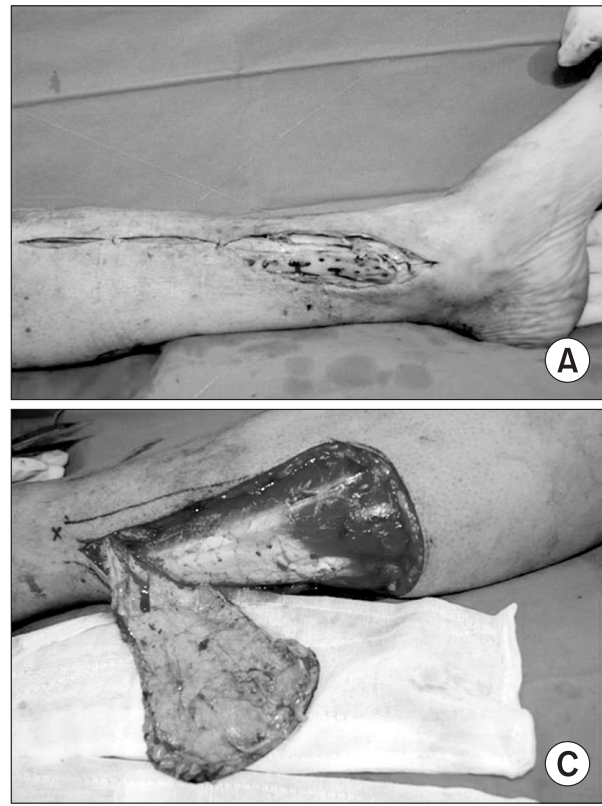

Figure 1. After plate removal and wound debridement $(A)$, the sural nerve and small saphenous vein were found (B). (C) Sural flap harvesting was performed. (D) Dissected flap was transferred to the recipient site. 
Soo-Hong Han, et al.

수술 후 1 주간은 가급적 관절운동 및 체중부하를 제한하였고 프로스타글란딘(60 $\mu \mathrm{g}$, quaque die [QD, everyday]) 정맥주사 및 아스피린(100 mg, QD) 경구약을 투여하였다. 이후 드레싱을 제거하여 수술 부위를 확인하고 이후에는 창상 및 골절 고정 양 상에 따라 치료 방침을 정하였다.

\section{결 과}

피판이 성공적으로 생존했다는 것은 피복 후 완전 괴사나 또 다 른 재건술이 필요한 합병증이 발생하지 않고 치유된 경우로 간주 하였다. 16명의 환자 모두에서 추시기간 내 피판은 성공적으로 생존하였으며, 공여부의 합병증은 발생하지 않았다.

총 8 예에서 피판부로 추가적인 수술을 시행되었는데, 1 예에서

Table 3. Postoperative Complications $(n=16)$

Variable

Number $(\%)$

Patients

Flap survival

$16(100)$

Donor site complications

$0(0)$

Cases required additional procedure

Hematoma

Partial necrosis

Debulking (cosmetic reason)

Hardware removal or provisional OR/IF

$3(18.8)$

Other problem

Transient venous congestion $1(6.3)$

OR/IF, open reduction/internal fixation.
는 경계부의 부분괴사 소견이 발견되었으나 변연절제술과 1차 봉합을 통해 회복되었다. 1 예에서 전경골동맥 분지에서의 가성 동맥류로 인하여 혈종이 발생하여 혈관결찰술 및 혈종제거술을 시행하였으며, 추시기간 내 피판은 성공적으로 생존하였다. 이식 된 피판의 두께를 줄여 외형상을 개선하기를 원하여 미용적 목적 으로 피판 축소술(debulking operation)이 3예에서 시행되었다. 피판이 안정적으로 생착된 뒤 3예에서 피판부에 절개를 시행하 여 내고정물 제거술 혹은 추가적 내고정술을 시행하였으며, 추가 적 수술 후 피판이 괴사된 경우는 없었다(Table 3).

1 예에서 일시적 정맥울혈 소견이 나타났으나 경과관찰 후 자 연회복되어 추가적인 수술적 치료를 요하지 않았다. 모든 환자에 서 피판술 직후 공여 원위부에 감각 저하가 있었으나 최종 추시 시에는 모두 적응하여 이에 대한 합병증이나 일상생활에서의 불 편을 호소한 예는 없었다.

\section{1. 증례 1}

27세 남자 환자로 사다리에서 추락하며 발생한 개방성 종골 골 절로 인해 관혈적 정복술 및 내고정술을 시행받았으며 수술 후 지속되는 원형의 연부조직 결손으로 내고정물이 노출되어 입원 하였다. 변연절제술 및 소파술 후 역행성 표재 비복동맥 피판술 을 시행하였으며, 피판의 크기는 $4 \times 4 \mathrm{~cm}^{2}$ 였고 피판경의 길이는 $8 \mathrm{~cm}$ 였다. 공여부는 일차 봉합하였다. 공여부와 피판은 합병증 없이 생존하였다(Fig. 2).

\section{2. 증례 2}

49세 남자 환자로 작업 도중 낙상하여 발생한 개방성 경골 및 비 골 골절로 입원하였다. 내고정술을 시행하였으나 수술 8주 후까 지 연부조직 결손이 회복되지 않고 피부괴사가 진행하여 역행성
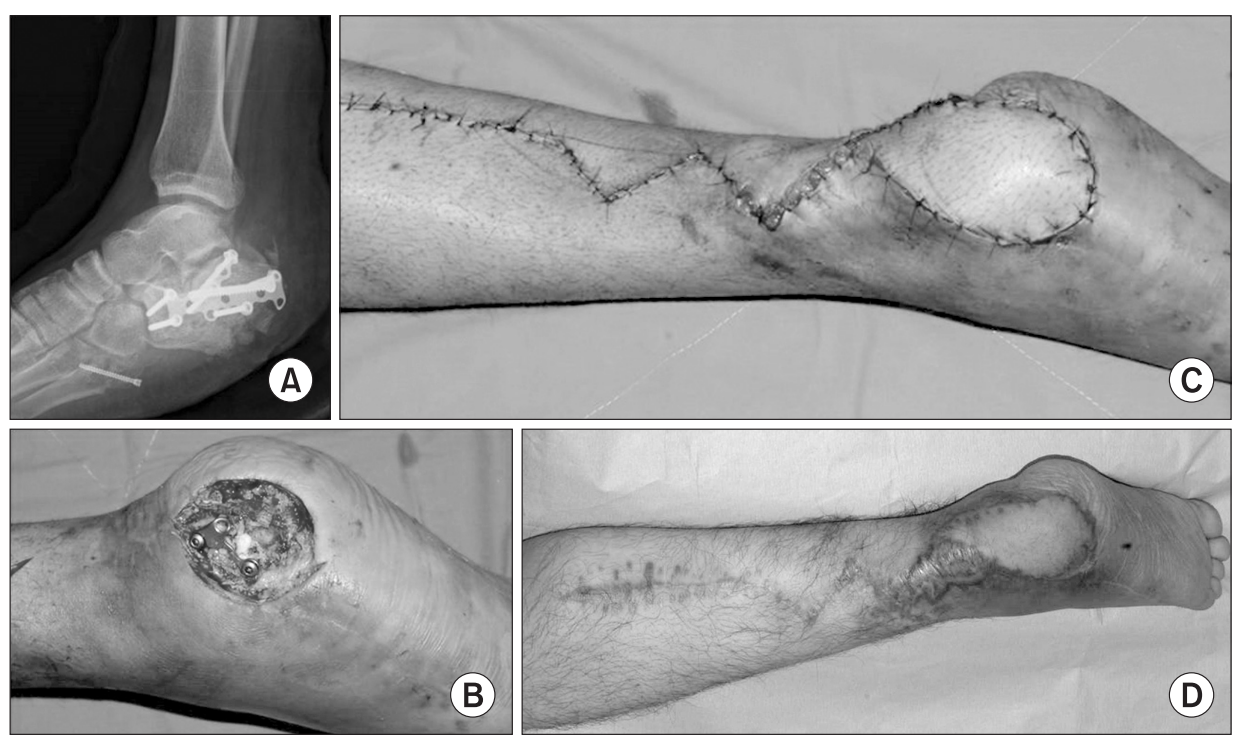

Figure 2. A 27-year-old male with a soft tissue defect on the posterior heel. (A) Preoperational X-ray is shown. (B) The right heel showed recurrent ulceration with plate exposure. (C) The dissected flap was elevated and transferred to the recipient site. The donor site was closed by primary repair. (D) At two months after surgery, there were no complications. 

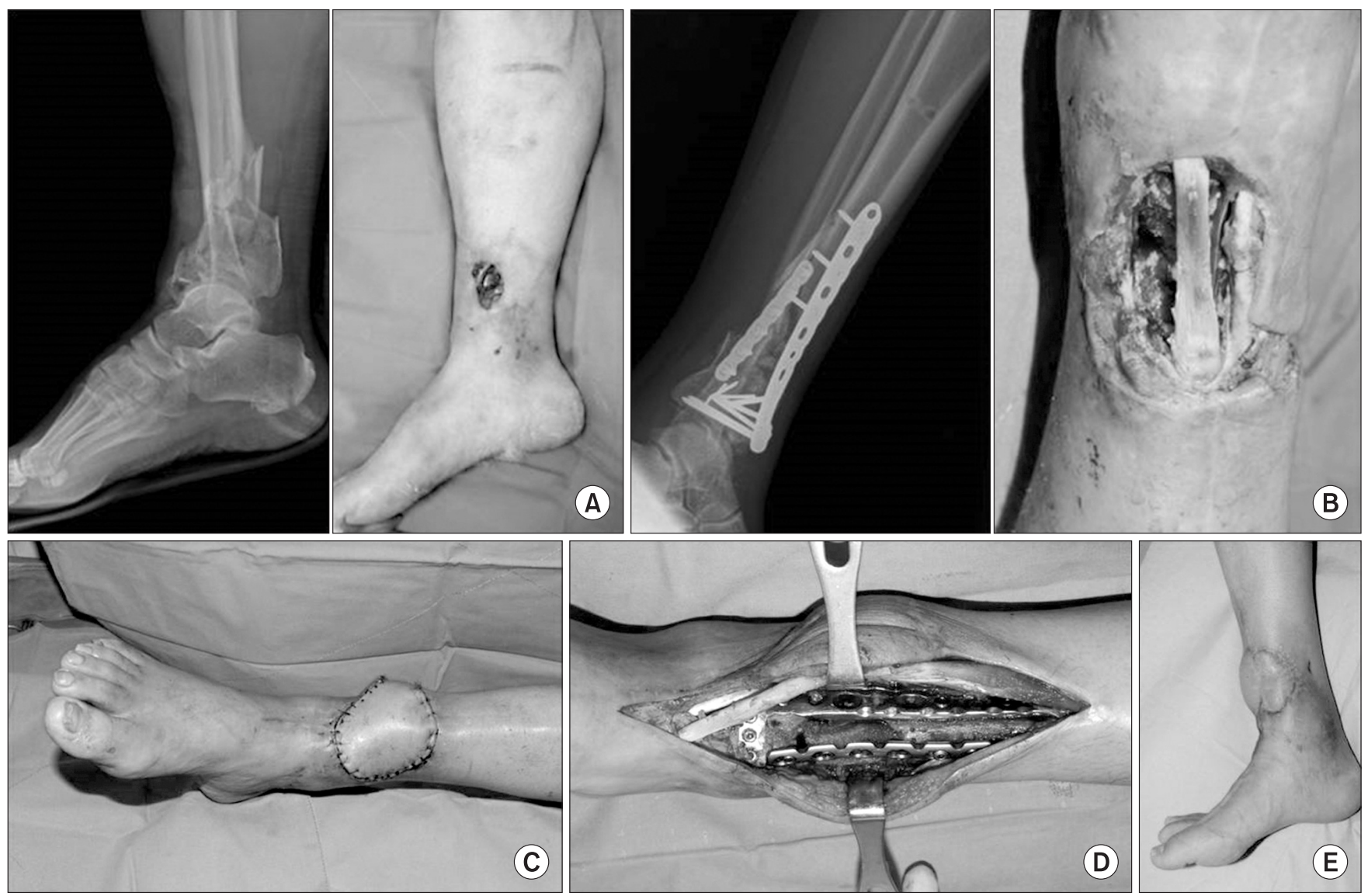

Figure 3. A 49-year-old male with an open pilon fracture. (A) A skin defect was found in the anteromedial area of the ankle. (B) Two months after open reduction and internal fixation (ORIF), skin necrosis was expanded to the anterior area of the ankle. (C) Reverse sural arterial flap was done with split thickness skin graft for the donor site. (D) Two months after the flap operations, nonunion of the fracture was found and additional ORIF was done. The dissection was performed through the healed flap. (E) Finally, the flap survived without complication.

표재성 비복동맥 피판술을 시행하였다. 피판의 크기는 $7 \times 5 \mathrm{~cm}^{2}$ 였고 피판경의 길이는 $7 \mathrm{~cm}$ 였다. 공여부는 대퇴부에서 부분층 피부이식술을 시행하였다. 피부이식술 8주 뒤, 골절부위의 불유 합 소견으로 자가골 이식을 포함한 추가적 내고정술을 시행하였 다. 수술 당시 건강한 피판을 확인하였으며, 피판을 절개하고 접 근하였다. 수술 후 피판은 별다른 합병증 없이 생존하였다(Fig. 3).

\section{고 찰}

하지 골절에 연부조직 결손은 흔하게 동반되는데, 경골천정부 골 절 후 발목 전방부 괴사, 외과골절 수술 부위의 괴사에 따른 금속 판 노출, 그리고 경골간부의 개방성 골절 후 안쪽 경골 부위 피 부 및 연부조직 결손 등이 특징적이다. 연부조직의 결손이 건, 혈 관, 신경, 그리고 뼈와 같은 중요 구조물을 노출시킬 경우 피복을 위해서는 여러 피판술을 고려해야 하는데, 본 연구는 16 예의 하 지 원위부, 발목, 그리고 발뒤꿈치의 연부조직 결손이 동반된 하 지 골절 환자에서 역행성 표재성 비복동맥 피판술을 시행하였고,
높은 생존율과 낮은 합병증을 통해 그 임상적 유용성을 확인하였 다.

역행성 비복동맥 피판술은 하지에서 가장 긴 근막피부 피판술 중 하나로 ${ }^{4}$ 피판은 비골동맥 관통지로부터 종아리의 근위 3 분의 4 지점까지 안전하게 박리될 수 있다. 하지 원위부, 발목 그리고 발뒤꿈치에서 유용하게 활용될 수 있으며 족부에는 사용에 제한 이 있다. 일반적으로 하지 원위부 3분의 1 지점의 피부 결손에 가 장 흔히 사용된다. ${ }^{5)}$ 공여부의 연부조직 손상 등의 문제가 없어야 하는 점을 주의해야 하며 문제 시에는 다른 피판술을 선택해야 할 것이다.

표재성 비복동맥은 슬와동맥 및 비복동맥에서 기시하여 소복 재정맥과 비복신경과 같이 주행하며, 장딴지상 3분의 1 에서 근 막을 뚫고 나온 후 근막의 상층에서 원위부로 주행하고 비복신경 과 피부에 작은 가지를 내며 내려오다가 족관절 외측과 약 3-5 $\mathrm{cm}$ 상방에서 비골동맥의 정맥피부(venocutaneous), 신경피부 (neurocutaneous) 천공지(perforator)와 문합을 이룬다. ${ }^{3,6,7)}$ 이 문합을 통해 비골동맥으로부터의 역행성 혈류가 비복동맥으로 


\section{Soo-Hong Han, et al.}

흘러 들어가는 것이 역행성 비복동맥 피판(reverse sural arterial flap)의 근간이 된다. 피판이 거상되었을 때 주된 혈액 공급원은 정맥 피부 천공지와 신경피부 천공지로 생각되고 있고, 장단지 근위부 3 분의 1 부터는 비복신경은 근막 하에 위치하지만 소복재 정맥 표재성 비복동맥과 함께 근막 상부에 위치하여 정맥피부 천 공지가 피부순환에 중대한 기여를 한다. 1994년 Hasegawa 등이 은 비복신경이 꼭 포함되지 않아도 피판이 생존하는 것을 확인하 고 비복신경은 동맥과 인접해 있을 뿐 피판의 생존에 필수이지는 않다고 보고하였으며, 표재 비복동맥 피판술(superficial sural artery flap)이라는 용어를 사용하였다. ${ }^{6-9)}$

Nakajima 등 ${ }^{10)}$ 은 소복재정맥에 동반하는 정맥피부 천공지에 기초하는 피판을 만들었고, Jeng과 Wei, ${ }^{11)} \mathrm{Mok}$ 등르은 내측 또 는 외측의 단일 비복신경 분지를 이용한 피판술을 사용하여 족부 외측부 감각을 보존하였다고 보고하였지만 단일 분지를 이용한 피판술은 그 피복범위에 제한이 있으며 아직까지 그 효용에 대한 논란이 있다. 본 연구에서는 비복신경을 절단하였으나 최종 추시 시에는 모두 적응하여 이에 대한 합병증이나 일상생활에서의 불 편을 호소한 예는 없었다.

정맥울혈은 피판 괴사의 주 원인으로 알려져 있으며, 이 때 피 하경 피판의 폭을 넓히는 것이 피판의 생존율 향상과 관련이 있 는 것으로 보인다. 역행성 비복동맥 피판은 소복재정맥과 동반정 맥(vena comitantes)을 통한 두 개의 정맥 배출로를 가지고 있는 데, 동반정맥은 판막이 없어 교통지(communicating branche), 측부지(collateral branch)에 의해 우회한 정맥 배출이 가능하 다. ${ }^{13)}$ 피판을 거상하는 과정에서 동반정맥의 신경이 제거되고, 정 맥 내 압력 형성으로 판막 기능이 저하되어 정맥배출을 더욱 용이하게 한다 ${ }^{14}$ 는 것이 피판의 정맥 배출의 이론적 근거가 된다. Almeida 등 $^{15)}$ 과 Sugg 등 ${ }^{16}$ 은 피하경 피판의 폭을 넓히는 것이 피판의 생 존율을 크게 향상시켰다고 주장하였다. Francesco 등ㄱㄱㄱㅘ Tan 등 ${ }^{18)}$ 은 복재정맥을 대복재정맥으로 문합하여 정맥울혈을 줄이 려 하였으나 이 방법은 문합을 위한 미세수술이 필요하다는 단점 이 있다. 본 연구에서는 피하경 피판의 크기를 3-4 cm로 보존하 고, 이전한 피판경 위 피부가 긴장 없이 봉합될 수 있도록 피판을 눈물방울 모양으로 설계한 것만으로 좋은 임상적 결과를 얻었다. 또한 동일 술식을 사용하여 아킬레스건 수술 후 상태에서 역행성 표재 비복동맥 피판술의 우수한 결과를 앞서 보고한 바 있다. ${ }^{19)}$

본 연구의 증례에서 공여부의 일차 봉합을 시행한 가장 큰 피 판의 크기는 $7 \times 7 \mathrm{~cm}^{2}$ 나 더 작은 크기의 피판에서도 피부이식술 이 필요했던 것으로 보아 환자의 연부조직의 유연성, 피부상태, 절개 모양에 따라 공여부의 일차 봉합 가능 여부를 판단해야 할 것으로 생각된다.

모든 피판술 전에 공히 해당되는 내용으로 피판술 전에 수여부 에 연부조직 감염 및 골수염이 완전히 배제되어야 한다. 본 연구 에서는 충분한 변연절제술을 통해 괴사나 감염이 의심되는 조직
이나 살 수 없는 조직(non-viable tissue)이 완전히 제거되고, 생 체 징후가 정상이며, 혈액검사상 감염소견이 호전된 상태에서 피 판술을 시행하였다. 뼈가 노출되어 골수염이 의심되는 경우에는 3 상 골스캔을 이용하여 감별하였으며, 증례 중 골수염이 의심되 는 경우는 없었다.

이 피판술의 단점은 일차 봉합이 이루어지지 않은 경우 공여부 의 흉터가 특히 여성에서 미용상 보기 좋지 않다는 것이다. 부분 괴사, 신경종 등의 합병증이 있어 수술 전 공여부의 이환율뿐 아 니라 족부 외측의 감각저하, 부분 괴사에 따르는 상처의 치료 지 연에 관한 설명이 미리 이루어져야 한다.

역행성 비복신경 피판술 외에도 국소피판술, 근이동술, 도서형 피판술 등이 각각의 장단점을 가지고 있다. 근이동술은 발 및 발 목관절에서 성공적이지 못하며, 천공지 기저 프로펠러플렙이은 술식이 간단하나 천공지의 꼬임에 의한 괴사의 위험성이 있고 넓 은 범위의 결손을 회복하기에 그 활용이 제한된다. 외측과상부 피판술 ${ }^{21}$ 은 비골동맥 천공지의 상행 분지로부터 혈액공급을 받 는 근막피부 또는 지방근막(adipofacial) 피판술로 공여부의 문 제가 적으면서 비복신경을 희생하지 않으며 비복동맥 피판보다 족배부 원위부의 결손을 덮어주는 데 유용한 술식이다. 하지만 특히 체중부하 부위의 피부결손의 복원에 역행성 비복신경 피판 술이 더 우수한 결과를 보여준다. ${ }^{22)}$

본 연구의 제한점 및 보완해야 할 점은 다음과 같다. 먼저, 본 연구는 후향적 연구이다. 적은 사례의 수도 향후 본 연구가 보완 해야 할 점이다. 피판술의 흔한 합병증이자 실패 원인인 정맥울 혈의 위험인자로 당뇨, 뇌혈관질환, 흡연의 과거력이 알려져 있 으나, ${ }^{23)}$ 본 연구에서는 대상군에 당뇨와 같은 동반질환이 있는 경 우가 적어 동반질환과 피판 괴사와 같은 합병증의 연관관계를 파 악할 수 없었다. 대상자 16명 중 11명은 특이 내과적 과거력이 없었으며, 4 명의 환자가 흡연력이 있었으나 피판의 성공률은 흡 연력이 없는 환자군과 차이를 보이지 않았다.

정리하자면 저자들은 피판의 생존율을 높이기 위해 이전한 피 판경 위 피부가 긴장 없이 봉합될 수 있도록 피판을 눈물방울 모 양으로 설계하였으며, 회전 중심에 인접한 관통지는 가능한 최대 한 보존하여 혈액 공급을 보장할 수 있게 하고, 상근막망(suprafascial network)을 통한 정맥혈 배출을 보존할 수 있도록 피하 경 피판은 폭이 최소 3-4 cm 이 되도록 유지하는 방법을 이용하 였으며 이로써 기존 연구보다 좋은 임상적 결과를 얻었다.

\section{결 론}

본 연구를 통해 하지 골절과 동반된 연부조직 결손에서 역행성 비복동맥 피판술의 유용성을 확인하였다. 역행성 표재 비복동맥 피판술은 미세현미경적 수술을 요하지 않으며 높은 생존율을 보 여 하지 골절과 동반된 연부조직 결손에서 선택할 수 있는 유용 
한 술기의 하나가 될 수 있을 것으로 생각된다.

\section{CONFLICTS OF INTEREST}

The authors have nothing to disclose.

\section{ORCID}

Soo-Hong Han, https://orcid.org/0000-0002-8951-650X

In-Tae Hong, https://orcid.org/0000-0002-0191-8417

SeongJu Choi, https://orcid.org/0000-0003-0524-6977

Minwook Kim, https://orcid.org/0000-0002-7584-2400

\section{REFERENCES}

1. de Blacam C, Colakoglu S, Ogunleye AA, et al. Risk factors associated with complications in lower-extremity reconstruction with the distally based sural flap: a systematic review and pooled analysis. J Plast Reconstr Aesthet Surg. 2014;67:607-16.

2. Saint-Cyr M, Wong C, Buchel EW, Colohan S, Pederson WC. Free tissue transfers and replantation. Plast Reconstr Surg. 2012;130:858e-78e.

3. Masquelet AC, Romana MC, Wolf G. Skin island flaps supplied by the vascular axis of the sensitive superficial nerves: anatomic study and clinical experience in the leg. Plast Reconstr Surg. 1992;89:1115-21.

4. Lamberty BG, Cormack GC. Fasciocutaneous flaps. Clin Plast Surg. 1990;17:713-26.

5. Colohan S, Saint-Cyr M. Management of lower extremity trauma. In: Neligan PC, Song DH, ed. Plastic surgery. Volume four: lower extremity, trunk, and burns. London: Elsevier Saunders; 2013. 63-91.

6. Hasegawa M, Torii S, Katoh H, Esaki S. The distally based superficial sural artery flap. Plast Reconstr Surg. 1994;93:101220.

7. Singh S, Naasan A. Use of distally based superficial sural island artery flaps in acute open fractures of the lower leg. Ann Plast Surg. 2001;47:505-10.

8. Rajacic N, Darweesh M, Jayakrishnan K, Gang RK, Jojic S. The distally based superficial sural flap for reconstruction of the lower leg and foot. Br J Plast Surg. 1996;49:383-9.

9. Ciofu RN, Zamfirescu DG, Popescu SA, Lascar I. Reverse sural flap for ankle and heel soft tissues reconstruction. J Med Life. 2017;10:94-8.
10. Nakajima H, Imanishi N, Fukuzumi S, et al. Accompanying arteries of the lesser saphenous vein and sural nerve: anatomic study and its clinical applications. Plast Reconstr Surg. 1999;103:104-20.

11. Jeng SF, Wei FC. Distally based sural island flap for foot and ankle reconstruction. Plast Reconstr Surg. 1997;99:744-50.

12. Mok WL, Por YC, Tan BK. Distally based sural artery adipofascial flap based on a single sural nerve branch: anatomy and clinical applications. Arch Plast Surg. 2014;41:709-15.

13. Imanishi N, Nakajima H, Fukuzumi S, Aiso S. Venous drainage of the distally based lesser saphenous-sural veno-neuroadipofascial pedicled fasciocutaneous flap: a radiographic perfusion study. Plast Reconstr Surg. 1999;103:494-8.

14. Timmons MJ. The vascular basis of the radial forearm flap. Plast Reconstr Surg. 1986;77:80-92.

15. Almeida MF, da Costa PR, Okawa RY. Reverse-flow island sural flap. Plast Reconstr Surg. 2002;109:583-91.

16. Sugg KB, Schaub TA, Concannon MJ, Cederna PS, Brown DL. The reverse superficial sural artery flap revisited for complex lower extremity and foot reconstruction. Plast Reconstr Surg Glob Open. 2015;3:e519.

17. Francesco G, Kolker D, Michael HR. Modified reverse sural artery flap with improved venous outflow in lower-leg reconstruction. Ann Plast Surg. 2007;59:563-5.

18. Tan O, Atik B, Bekerecioglu M. Supercharged reverse-flow sural flap: a new modification increasing the reliability of the flap. Microsurgery. 2005;25:36-43.

19. Choi YR, Lee SY, Lee SC, Lee HJ, Han SH. Reverse superficial sural artery flap for the reconstruction of soft tissue defect on posterior side of heel exposing achilles tendon. J Korean Soc Microsurg. 2012;21:159-64.

20. Rad AN, Singh NK, Rosson GD. Peroneal artery perforator-based propeller flap reconstruction of the lateral distal lower extremity after tumor extirpation: case report and literature review. Microsurgery. 2008;28:663-70.

21. Han SH, Kim SH, Lee SC, et al. Lateral supramalleolar flap for reconstruction of soft tissue defect around the ankle joint. Arch Reconstr Microsurg. 2014;23:13-17.

22. Price MF, Capizzi PJ, Watterson PA, Lettieri S. Reverse sural artery flap: caveats for success. Ann Plast Surg. 2002;48:496-504.

23. Baumeister SP, Spierer R, Erdmann D, Sweis R, Levin LS, Germann GK. A realistic complication analysis of 70 sural artery flaps in a multimorbid patient group. Plast Reconstr Surg. 2003;112:129-40. 


\section{하지골절과동반된 연부조직 결손재건을위한 역행성비복동맥피판술 한수홍 • 홍이낼 • 초성주 • 김미욱}

차의과학대학교 분당차병원 정형외과학교실, *한림대학교 동탄성심병원 정형외과

목적: 하지, 특히 정강이 앞 부분이나 발, 발목에서의 연부조직 결손은 피복에 어려움이 있다. 저자들은 하지의 개방성 골절 또는 폐쇄적 골절 후 수상부위에 발생한 다양한 연부조직 결손에 대하여 역행성 표재 비복동맥 피판술을 사용하여 피복을 시행한 예들 을 수집, 분석하여 그 임상적 결과를 보고하고자 한다.

대상 및 방법: 2003년 8월부터 2018년 4월까지 하지의 골절 후 수상 부위에 발생한 연부조직 결손에 대하여 역행성 비복동맥 피 판술을 시행받은 환자를 대상으로 하였다. 수술 후 최소 6 개월 추시가 가능했던 16 명의 환자를 대상으로 하였으며, 평균 추시기 간은 18 개월이었다. 8 예는 개방성, 다른 8 예는 폐쇄적 골절 후 발생한 합병증으로 연부조직 결손이 발생했다. 피판의 평균크기는 $51.9 \mathrm{~cm}^{2}$ 였으며, 가장 큰 피판의 크기는 $10 \times 15 \mathrm{~cm}^{2}$ 였다. 결과 분석을 위해 수술 후 피판의 생존 여부와 추가 술식, 합병증 등을 조사하였다.

결과: 최종 추시 시 이식 피판은 모두 생존하였으며, 공여부에 별다른 합병증도 발생하지 않았다. 수술 후 단기 추시 당시 1예에서 경계부의 부분 괴사 소견이 발견되었으나 변연절제술과 1 차 봉합을 통해 회복되었다. 다른 1 예에서는 혈종이 발생하여 추가로 혈 종제거술을 시행하였으며, 추시기간 내 피판은 성공적으로 생존하였다. 이식부의 미용적 목적으로 피판 축소수술이 3예에서 시행 되었고, 피판부를 절개하고 접근하여 내고정물을 제거하거나 추가적 내고정술을 시행한 건이 3예였었다.

결론: 역행성 표재 비복동맥 피판술은 하지 골절과 동반된 연부조직 결손의 치료에 있어 적극적 적용을 고려할 만한 유용한 술기 의 하나가 될 수 있을 것으로 생각된다.

색인단어: 하퇴부, 연부조직 결손, 역행성 표재 비복동맥 피판술

접수일 2019년3월 19일 수정일 2019년 5월 8일 게재확정일 2019년 7월 11일 책임저자한수홍

13496 , 성남시 분당구 야탑동 야탑로 59 , 차의과학대학교 분당차병원 정형외과학교실

TEL 031-780-5289, FAX 031-708-3578, E-mail hsoohong@cha.ac.kr, ORCID https://orcid.org/0000-0002-8951-650X 